\title{
Molecular Analysis of JC Polyomavirus Genotypes Circulating Among Tribal Populations of North-Eastern West Bengal, India
}

\author{
SUTANUKA CHATTARAJ and SOUMEN BHATTACHARJEE* \\ Cell and Molecular Biology Laboratory, Department of Zoology, University of North Bengal, Raja Rammohunpur, \\ P.O. NBU, Siliguri, District - Darjeeling, West Bengal, PIN - 734 013, India
}

Submitted 26 November 2013, revised 7 April 2014, accepted 12 May 2014

\begin{abstract}
There is a resurgence of interest in the study of occurrence, genotype and pathogenic associations of human Polyomaviruses in recent years. In the present study, we have ascertained the presence of human Polyomavirus JC (JCV) in the urine and peripheral blood leukocytes of tribal populations, for the first time in the North-Eastern part of West Bengal State of India. We have also characterized the prevalent genotypes of the non-coding control regions (NCCRs) of these natural isolates. The result suggests a high incidence of JCV reactivation in the populations assayed. Approximately $25 \%$ of the non-immunocompromized tribal men and women, tested positive based on polymerase chain reaction (PCR) analysis, and these results were further confirmed by sequencing of PCR products. Pairwise sequence comparison and alignment of the NCCR sequence of these Indian strains appeared to be comparable and related to the archetypal JCV (CY) and the Tibetan LH3 strains, with some alterations in few key positions. The sequence analyses were done with regard to transcription factor binding to DNA sequence elements of endemic JCV NCCRs.
\end{abstract}

Ke y word s: JC Polyomavirus, NCCR, North-East India, TFBS

\section{Introduction}

JC virus (JCV), a member of the Polyomaviridae family, was first isolated from brain tissue of a 38 year old man with initials - JC, who was suffering from Hodgkin's disease for a quite a long time (Padgett et al., 1971). JC virus has simple genome containing a single molecule of covalently closed, circular double-stranded DNA of about 5000 base pair in length (Frisque et al., 1984). The viral genome comprises early and late coding regions that are controlled by a common Non-Coding Control Region (NCCR), which lies between them. The early proximal side of the NCCR is highly conserved and contains the origin of viral DNA replication. The late proximal side of the NCCR contains the repetitive enhancer elements and undergoes rearrangements that account for most of the differences between different strains of the same virus.

Transcriptional regulation of the JCV early and late promoters during the viral lytic cycle is a complicated event that requires participation of both viral key proteins and cellular transcription factors. Several transcription factors are implicated in the regulation of
JCV gene expression which include NF- $\mathrm{BB}$ (Ranganathan and Khalili, 1993), NFAT4 (Wollebo et al., 2012), upstream Target or up-TAR (Chowdhury et al., 1993), Tst-1 (Wegner et al., 1993), Sp-1 (Henson et al., 1992), Spi-B (Marshall et al., 2010), GBP-i (Raj and Khalili, 1994), Y-box binding protein 1 (YB-1) and Pura (Chen and Khalili, 1995), Nuclear factor 1 or NF-1 (Amemiya et al. 1989), CREB/ATF-1 (Lonze and Guinty, 2002), Activator Protein 1 (AP-1) family members (Sadowska etal., 2003), p53 (Ariza et al., 1994), Early growth response-1 protein or Egr-1 (Romagnoli et al., 2008), Bcl-2-associated athano gene-1 or BAG-1 (Devireddy et al., 2000) and CAAT/enhancer binding protein beta or C/EBP $\beta$ (Romagnoli et al., 2009).

JC polyomavirus is widespread in the human population and causes a rare fatal brain infection known as Progressive Multifocal Leucoencephalopathy (PML). PML occurs mainly in a limited number of individuals with suppressed immune system, especially in those with Human Immunodeficiency Virus (HIV) infection/ AIDS (Hou and Major, 2000; Khalili et al., 2006) and involves productive infection in both oligodendrocytes and astrocytes. However, there are reports where

* Corresponding author: S. Bhattacharjee, Cell and Molecular Biology Laboratory, Department of Zoology, University of North Bengal Raja Rammohunpur, P.O. NBU, Siliguri District - Darjeeling West Bengal PIN - 734 013, India; phone: +91-0353-2776353 (0)/ +919474674013 (M); fax: +91-0353-2699001; e-mail: soumenb123@rediffmail.com, sbhnbu@gmail.com 
researchers have shown that JCV can even induce PML in non-immunocompromised individuals without AIDS, such as patients receiving monoclonal antibody natalizumab (Langer-Gould et al., 2009). JCV exists in ten or more geographically based genotypes identified in the United States, Africa, Europe and Asia (Agostini et al., 1997; Sugimoto et al., 2002). There appear to be several Asian subtypes and the Indian subtype has been designated as Type 2D (Cui et al., 2004).

In this study, we have screened urine and blood samples from tribal/ethnic human population of northeastern part of West Bengal state of India to record for the first time the JCV reactivation status and to ascertain the prevalent nature of endemic viral NCCRs. Specific oligonucleotide primers were used to amplify the JCV NCCRs by PCR and then sequenced to analyze their genetic architectures. We have recorded about $25 \%$ of the subjects to be positive for JCV NCCRs. Analyses of predicted transcription factor binding sites (TFBS) revealed additional putative promoter elements in endemic NCCRs capable of binding to a diverse set of human/vertebrate transcription factors. Further in vivo and in vitro experiments are expected to substantiate these findings.

\section{Experimental}

\section{Materials and Methods}

Sample collection. The study methodology was approved by our institutional Human Ethical Committee. A total of 77 samples were collected from the tribal, non-immunosuppressed populations of the north-eastern part of West Bengal State of India with their prior informed consent. The samples included either urine or blood specimens from each individual. The collected samples were from two tribal groups of North Bengal - Oraon and Mundas of Kiran Chandra tea garden, Naxalbari, Darjeeling district $\left(26^{\circ} 41^{\prime} \mathrm{N}\right.$ Lat; $88^{\circ} 16^{\prime}$ E Long) and Rabha or Rava population of Poro Busty, Tufanganj, Coochbehar district $\left(26^{\circ} 18^{\prime} \mathrm{N}\right.$ Lat; $89^{\circ} 39^{\prime} \mathrm{E}$ Long). The urine samples were collected in $1.5 \mathrm{ml}$ eppendorf tubes and about $1 \mathrm{ml}$ of blood samples were collected in vials containing EDTA. All the samples were brought to the laboratory and stored at $-20^{\circ} \mathrm{C}$ refrigerator prior to DNA isolation.

DNA Isolation. DNA isolation from urine and blood samples was done using the High Pure Viral Nucleic Acid Kit (Roche Diagnostic GmbH, Germany) as per the manufacturer's instruction. In brief, $200 \mu \mathrm{l}$ of freshly prepared working solution (carrier RNAsupplemented binding buffer) and $50 \mu$ l of Proteinase $\mathrm{K}$ solution was added to $200 \mu \mathrm{l}$ of sample and incubated at $72^{\circ} \mathrm{C}$ for 10 minutes. Then $100 \mu \mathrm{l}$ of binding buffer was added and centrifuged at $8,000 \times \mathrm{g}$ for $1 \mathrm{~min}$. The flowthrough liquid was discarded and $500 \mu \mathrm{l}$ of inhibitor removal buffer was added and centrifuged again at $8,000 \times \mathrm{g}$ for $1 \mathrm{~min}$. After discarding the flow through, samples were washed twice with $450 \mu$ l wash buffer. The last step included addition of $50 \mu$ l elution buffer followed by centrifugation at $8,000 \times \mathrm{g}$ for $1 \mathrm{~min}$. The isolated DNA samples were stored in $-20^{\circ} \mathrm{C}$ refrigerator until used for PCR amplification.

Standard Viral DNA. Plasmid pMITC-BSMKS containing the whole JCV genome (JCV Mad-1 strain) was a gift from Richard J. Frisque, Department of Biochemistry, Microbiology, Molecular \& Cell Biology, Pennsylvania State University, USA. The plasmid pGMTW3JCV containing the whole genome of JCV (JCV Taiwan-3 strain) was gifted by Deching Chang, National Chung Cheng University, Taiwan.

PCR amplification and Electrophoretic analysis of endemic JCV NCCRs. Two oligonucleotide primers namely SDJ1 (5'-CCCTATTCAGCACTTTGTCC-3') and SDJ2 (5'-CAAACCACTGTGTCTCTGTC-3') were used for the amplification of the viral control region DNA. A final volume $50 \mu \mathrm{l}$ PCR reaction mixture contained $20 \mathrm{pM}$ of each primer, $200 \mu \mathrm{M}$ dNTPs (NEB, USA), $10 \mathrm{X}$ standard Taq buffer containing $\mathrm{MgCl}_{2}$ (NEB, USA) and Taq Polymerase enzyme (NEB, USA). Twenty microlitres of isolated DNA was used for each PCR amplification reaction. Amplifications were performed in an Applied Biosystems Thermal Cycler (Model: 2720 Thermal Cycler, Life Technologies, USA) programmed for initial heating at $94^{\circ} \mathrm{C}$ for $5 \mathrm{~min}, 25$ cycles at $94^{\circ} \mathrm{C}$ for $1 \mathrm{~min}$, annealing at $56^{\circ} \mathrm{C}$ for $1 \mathrm{~min}$, and extension at $72^{\circ} \mathrm{C}$ for $1 \mathrm{~min}$. A final extension was performed at $72^{\circ} \mathrm{C}$ for $5 \mathrm{~min}$. The cloned JCV genome plasmids pMITC-BSMKS or pGMTW3JCV were used as positive control in each reaction and sterile distilled water was used as negative control. PCR products were run on 1\% agarose gel containing $0.5 \mu \mathrm{g} / \mathrm{ml}$ of Ethidium bromide at $80 \mathrm{~V}$ for 1 hour approximately in a Bench Top Lab Systems (Model: BT-MS-300, Taiwan) electrophoresis apparatus and then visualized in a UV transilluminator (Spectroline BI-O-Vision UV/White Light Transilluminator, NY, USA).

Sequence Analysis. Sequencing of the JC virus NCCR PCR product from each positive sample was done at least twice by dye-dideoxy automated chain termination method (Biolinkk, New Delhi, India) and only six of them were deposited in NCBI public domain for GenBank accession. All the remaining NCCR sequences were similar to the ones deposited for GenBank accession. Submission IDs are as follows: NB1 (JX294575), NB2 (JX534216), NB3 (JX534217), NB4 (JX534218), NB5 (JX534219) and NB6 (JX534220). Nucleotide sequences of the endemic JCV NCCRs were aligned with the known NCCR sequences of JCV 
strains CY, LH3, Tai3, IN-8 and Mad-1 using DiAlign alignment program of Genomatix suite v2.5 $\mathrm{GmbH}$ (Cartharius et al., 2005) to compare pairwise similarities (relative to the maximum similarity) among these sequences. All NCCR sequences (T-antigen coding start site to Agnogene coding start site) were again aligned in ClustalX ver. 2.0.3 (Thompson et al., 1997) using default parameters, curated in BioEdit ver. 7.0.9.0 (Hall, 1999) to generate an alignment showing deletion/mutation and common transcription factor binding sites derived from experimental data of other research groups. The NCCR sequences of NB3, 4 and 5 being identical only NB3 was included in the multiple sequence alignment. The MatInspector program of Genomatix Software suite v2.5 GmbH (Cartharius et al., 2005) was used to search for the predicted transcription factor binding sites (TFBS) in the aligned portion of endemic using a large library of weight matrices based on general core promoter and vertebrate promoter matrix families.

\section{Results}

PCR amplification and Electrophoretic analyses. PCR amplification of JCV specific NCCR from all urine as well as from blood samples was done to check the prevalence of the virus in the North Bengal region of India. Seventy-seven samples of urine and blood were collected from the tribal, non immunosuppressed populations of this region. Twenty-four samples were from Kiran Chandra tea garden, Naxalbari, Darjeeling district and 53 samples were collected from Poro busty, Tufangunj, Coochbehar district of West Bengal. The two primers SDJ1 and SDJ2 specific for NCCR region amplified a product of approximately $586 \mathrm{bp}$ of DNA. After PCR amplification, products were analysed by agarose gel electrophoresis (Fig. 1). Seven out of 24 assayable samples from the Oraon and Munda tribal groups in Kiran Chandra tea garden were found to be JCV positive showing an overall incidence of $29.17 \%$. In Poro busty, Tufangunj, having mostly Rabha tribal population, 12 out of 53 samples supported positive

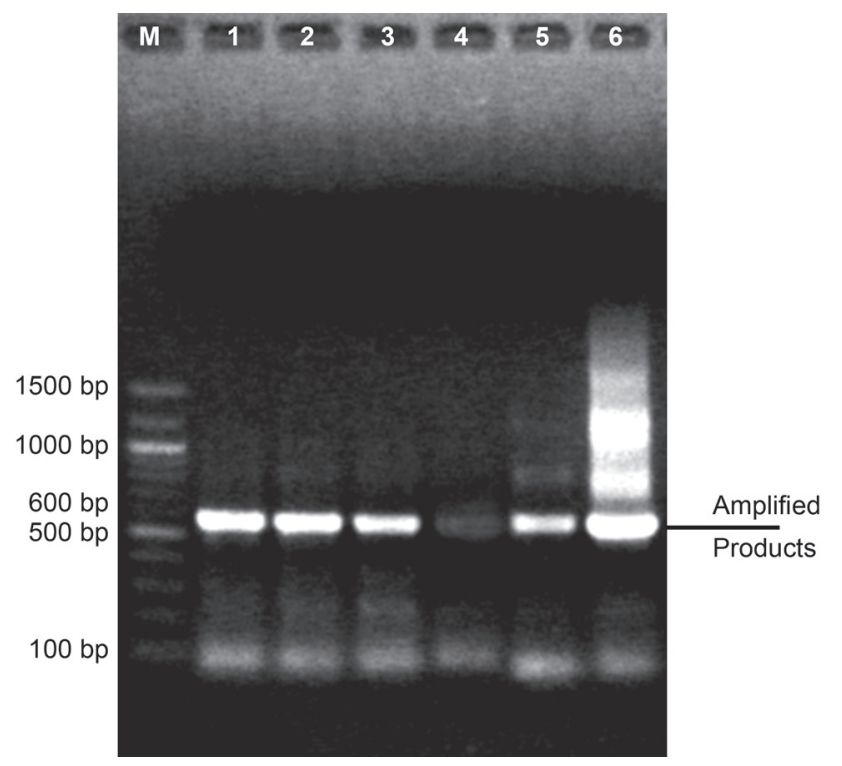

Fig. 1. Agarose gel showing amplified JCV Non Coding Control Region in tribal populations of North-East India.

Lane 1: 100 bp ladder; Lane 2: JCV NB1 NCCR; Lane 3: JCV NB2 NCCR; Lane 4: JCV NB3 NCCR; Lane 5: JCV NB4 NCCR; Lane 6: JCV NB5 NCCR; Lane 7: JCV NB6 NCCR.

amplification of the JCV NCCR region having an overall incidence of $22.64 \%$ (Table I). Thus the overall incidence of JCV control region DNA in urine and blood of non-immunosuppressed general tribal population was found to be $24.67 \%$ (19 out of 77 individuals) in this north-eastern part of India.

Pairwise Comparison of endemic JCV NCCRs with strains reported from North-East and South-East Asia. NCCR region is the variable segment of the viral genome except the early proximal part of the sequence which is highly conserved. In this study, DiAlign program of the Genomatix software suite (Table II) was used to check only the similarity of NCCR sequences among the six endemic isolates of JCV namely NB1, NB2, NB3, NB4, NB5 (from Oraon and Munda Tribes of Kiranchandra Tea Garden, Darjeeling District) and NB6 (from Rabha Tribes of Poro Busty, Coochbehar District) of this region and also with different strains from other regions such as archetypal CY, LH3, Tai3, IN-8 and

Table I

Summary of results obtained in different tribal groups showing incidences of JCV Non-Coding Control Region DNA detection

\begin{tabular}{|c|c|c|c|c|c|c|}
\hline Location & Tribal group & Sex & Median age & Positive & Negative & Total \\
\hline $\begin{array}{l}\text { Kiran Chandra Tea Garden, Naxalbari, Darjeeling District } \\
{\left[26^{\circ} 41^{\prime} \mathrm{N} \text { Lat; } 88^{\circ} 16^{\prime} \text { E Long; Elev. } 772 \mathrm{ft} \mathrm{msl}\right]}\end{array}$ & $\begin{array}{l}\text { Oraon } \\
\text { and Munda }\end{array}$ & $\begin{array}{l}\mathrm{F}=20 \\
\mathrm{M}=4\end{array}$ & $\begin{array}{l}\mathrm{F}=26 \\
\mathrm{M}=42\end{array}$ & $\begin{array}{c}\mathrm{F}=3 \\
\mathrm{M}=4 \\
7(29.17 \%)\end{array}$ & 17 & 24 \\
\hline $\begin{array}{l}\text { Poro Busty, Tufanganj, Coochbehar District } \\
\text { [261’N Lat; } 89^{\circ} 39^{\prime} \text { E Long; Elev. } 134 \mathrm{ft} \mathrm{msl]}\end{array}$ & Rabha & $\begin{array}{l}\mathrm{F}=20 \\
\mathrm{M}=33\end{array}$ & $\begin{array}{l}\mathrm{F}=59 \\
\mathrm{M}=40\end{array}$ & $\begin{array}{c}\mathrm{F}=01 \\
\mathrm{M}=11 \\
12(22.64 \%)\end{array}$ & 41 & 53 \\
\hline Total & & $\begin{array}{l}\mathrm{F}=40 \\
\mathrm{M}=37\end{array}$ & $\begin{aligned} \mathrm{F} & =40 \\
\mathrm{M} & =26.5\end{aligned}$ & $19(24.67 \%)$ & 58 & 77 \\
\hline
\end{tabular}


Table II

Pairwise similarities (relative to the maximum similarity) based on Non-Coding Control Regions (NCCRs) of endemic JCV strains NB1, 2, 3, 4, 5, 6 in comparison to archetype CY, Mad1, LH3, Tai3 and IN8 NCCRs using DiAlign alignment software of Genomatix suite v2.5 GmbH. The number of identical nucleic acids (\% of shorter sequence) and maximum values (underlined) are shown

\begin{tabular}{|c|c|c|c|c|c|c|c|c|c|c|}
\hline & $\begin{array}{c}\text { NB2 } \\
\text { JX534216 } \\
(372 \text { bp })\end{array}$ & $\begin{array}{c}\text { NB3 } \\
\text { JX534217 } \\
\text { (372 bp) }\end{array}$ & $\begin{array}{c}\text { NB4 } \\
\text { JX534218 } \\
\text { (372 bp) }\end{array}$ & $\begin{array}{c}\text { NB5 } \\
\text { JX534219 } \\
(372 \text { bp) }\end{array}$ & $\begin{array}{c}\text { NB6 } \\
\text { JX534220 } \\
\text { (383 bp) }\end{array}$ & $\begin{array}{c}\text { CY } \\
\text { AB038249 } \\
\text { (384 bp) }\end{array}$ & $\begin{array}{c}\text { LH3 } \\
\text { AB262411 } \\
\text { (382 bp) }\end{array}$ & $\begin{array}{c}\text { Tai3 } \\
\text { U61771 } \\
\text { (374 bp) }\end{array}$ & $\begin{array}{c}\text { IN8 } \\
\text { AB126992 } \\
\text { (384 bp) }\end{array}$ & $\begin{array}{c}\text { Mad1 } \\
\text { NC_001699 } \\
\text { (393 bp) }\end{array}$ \\
\hline NB1|JX294575 (372 bp) & $\begin{array}{c}0.943 \\
98 \%\end{array}$ & $\begin{array}{c}0.950 \\
98 \%\end{array}$ & $\begin{array}{c}0.950 \\
98 \%\end{array}$ & $\begin{array}{c}0.950 \\
98 \%\end{array}$ & $\begin{array}{c}0.896 \\
94 \%\end{array}$ & $\begin{array}{c}0.920 \\
95 \%\end{array}$ & $\begin{array}{c}0.927 \\
97 \%\end{array}$ & $\begin{array}{c}0.886 \\
94 \%\end{array}$ & $\begin{array}{c}0.920 \\
95 \%\end{array}$ & $\begin{array}{c}0.721 \\
79 \%\end{array}$ \\
\hline NB2|JX534216 (372 bp) & & $\begin{array}{c}0.962 \\
99 \%\end{array}$ & $\begin{array}{c}0.962 \\
99 \%\end{array}$ & $\begin{array}{c}0.962 \\
99 \%\end{array}$ & $\begin{array}{c}0.908 \\
96 \%\end{array}$ & $\begin{array}{c}0.921 \\
97 \%\end{array}$ & $\begin{array}{c}0.938 \\
98 \%\end{array}$ & $\begin{array}{c}0.889 \\
93 \%\end{array}$ & $\begin{array}{c}0.915 \\
97 \%\end{array}$ & $\begin{array}{c}0.683 \\
80 \%\end{array}$ \\
\hline NB3|JX534217 (372 bp) & & & $\begin{array}{l}0.976 \\
100 \%\end{array}$ & $\begin{array}{l}0.976 \\
100 \%\end{array}$ & $\begin{array}{c}0.909 \\
96 \%\end{array}$ & $\begin{array}{c}0.936 \\
97 \%\end{array}$ & $\begin{array}{c}0.954 \\
98 \%\end{array}$ & $\begin{array}{c}0.904 \\
94 \%\end{array}$ & $\begin{array}{c}0.923 \\
97 \%\end{array}$ & $\begin{array}{c}0.684 \\
78 \%\end{array}$ \\
\hline NB4|JX534218 (372 bp) & & & & $\begin{array}{l}0.976 \\
100 \%\end{array}$ & $\begin{array}{c}0.909 \\
96 \%\end{array}$ & $\begin{array}{c}0.936 \\
97 \%\end{array}$ & $\begin{array}{c}0.954 \\
98 \%\end{array}$ & $\begin{array}{c}0.904 \\
94 \%\end{array}$ & $\begin{array}{c}0.923 \\
97 \%\end{array}$ & $\begin{array}{c}0.684 \\
78 \%\end{array}$ \\
\hline NB5|JX534219 (372 bp) & & & & & $\begin{array}{c}0.909 \\
96 \%\end{array}$ & $\begin{array}{c}0.936 \\
97 \%\end{array}$ & $\begin{array}{c}0.954 \\
98 \%\end{array}$ & $\begin{array}{c}0.904 \\
94 \%\end{array}$ & $\begin{array}{c}0.923 \\
97 \%\end{array}$ & $\begin{array}{c}0.684 \\
78 \%\end{array}$ \\
\hline NB6|JX534220 (383 bp) & & & & & & $\begin{array}{c}0.962 \\
98 \%\end{array}$ & $\begin{array}{c}0.935 \\
95 \%\end{array}$ & $\begin{array}{c}0.912 \\
97 \%\end{array}$ & $\begin{array}{c}0.954 \\
97 \%\end{array}$ & $\begin{array}{c}0.676 \\
78 \%\end{array}$ \\
\hline CY|AB038249 (384 bp) & & & & & & & $\begin{array}{c}0.981 \\
97 \%\end{array}$ & $\begin{array}{c}0.965 \\
98 \%\end{array}$ & $\begin{array}{c}1.000 \\
99 \%\end{array}$ & $\begin{array}{c}0.709 \\
79 \%\end{array}$ \\
\hline LH3|AB262411 (382 bp) & & & & & & & & $\begin{array}{c}0.961 \\
98 \%\end{array}$ & $\begin{array}{c}0.967 \\
97 \%\end{array}$ & $\begin{array}{c}0.695 \\
79 \%\end{array}$ \\
\hline Tai3|U61771 (374 bp) & & & & & & & & & $\begin{array}{c}0.950 \\
98 \%\end{array}$ & $\begin{array}{c}0.667 \\
74 \%\end{array}$ \\
\hline IN8|AB126992 (384 bp) & & & & & & & & & & $\begin{array}{c}0.722 \\
79 \%\end{array}$ \\
\hline
\end{tabular}

* The similarity value 1.000 marks only the two most similar sequences; it does not necessarily mean that these sequences are identical.

Mad-1 strains. It was evident from the study that the NCCR sequences of NB3, 4 and 5 were identical. All the NCCR sequences (NB1-5) except the NB6 paired closely with each other (98-100\% similar). Pairwise sequence comparison with other strains revealed that the NCCR sequence of NB1, 2, 3, 4 and 5 were almost similar to the Tibetan LH3 (97-98\% similar) NCCR sequence and the NB6 NCCR sequence seemed almost identical with CY strain (98\% similarity). These NCCR sequences including that of NB6 were divergent from Tai3, IN-8 and as expected from Mad-1 control regions.

Analyses of NCCRs for Transcription Factor Binding Sites (TFBS). Multiple sequence alignment of endemic JCV NCCRs and other strains reported earlier revealed a 10 nucleotide (169-178) and a di-nucleotide (454-455) deletions in NB1, 2, and 3 (and also in NB5 and NB6) but not in NB6 (Fig. 2). Point mutations in seven different sites within the NCCR of the endemic strains recorded are at 4, 13, 26, 27, 69, 226 and 452 nucleotide positions of the sequence alignment (Fig. 2).

Several transactivating factors have been experimentally shown to bind to JCV NCCR either individually or cooperatively with other cellular factors and/or virus encoded proteins. The binding motifs of NF- $\mathrm{kB}$, NFAT4, upstream Target or up-TAR, Tst-1, Sp-1, Spi-B, GBP-i, Y-box binding protein 1, Pura, Nuclear factor
1 or NF-1, CREB/ATF-1, Activator Protein 1 (AP-1) family members, p53, Early growth response-1 protein or Egr-1, Bcl-2-associated athano gene-1 or BAG-1 and CAAT/enhancer binding protein beta or $\mathrm{C} / \mathrm{EBP} \beta$ are shown on the aligned sequences (Fig. 2). In an effort to check further the binding of putative transcription factors to this control region in silico we have searched a well defined general core and vertebrate transcription factor matrix families in MatInspector program of the Genomatix software suite (Cartharius et al., 2005). Supplementary Table I shows putative binding sites of transcription factors in an abridged form. Matches for transcription factors that are reported to be active in cells/tissues such as antibody-producing cells, antigenpresenting cells, bone marrow cells, hematopoietic and immune system, leukocytes, lymphocytes, monocytes, myeloid cells, phagocytes, brain, CNS, endocrine system, kidney, nervous system, urinogenital system are retained in the table list.

\section{Discussion}

We report here, for the first time, the incidence and sequence characterization of human polyomavirus JCV non-coding control/regulatory regions or NCCRs, 


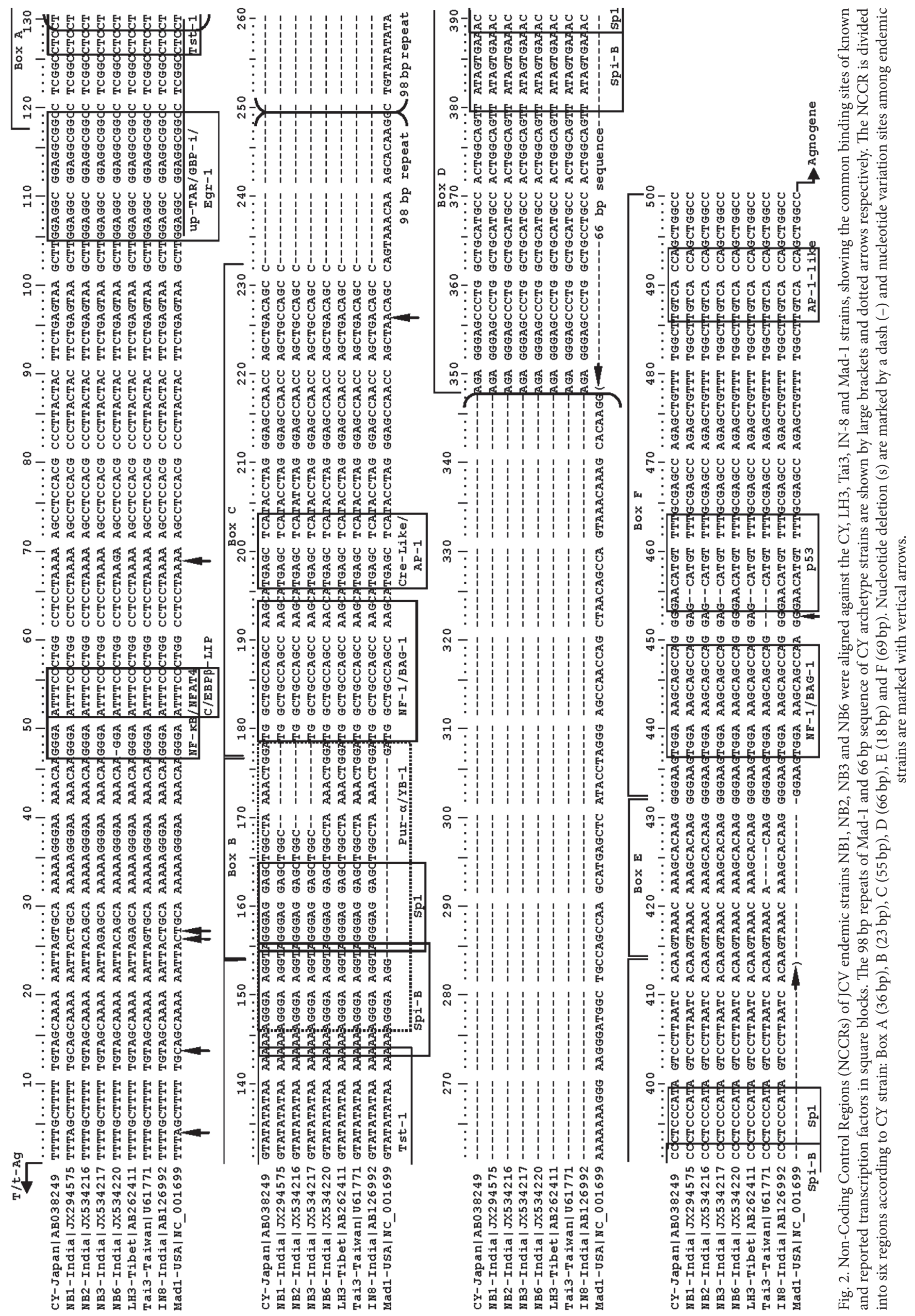


amplified directly from urine and blood samples of non-immunocompromized healthy tribal groups from north-eastern parts of West Bengal State of India. The objectives of the current investigation were (1) to document the prevalence or reactivation status of human polyomavirus JCV in non-immunosuppressed Indian tribal population, (2) to compare and contrast intergenic NCCR motifs of JCV variants found in healthy subjects with respect to transcription/transactivating factor binding and (3) to predict putative transcription factor binding sites within the endemic NCCR variants.

Initial infection with human polyomavirus seems to occur through the oral/respiratory route in childhood, as evidenced by detection of JCV DNA in infant tonsillar tissues, after which they remain in latent state in organs like kidneys, hematopoietic precursor cells, B-lymphocytes etc. till reactivation (Boldorini etal., 2003; Dorries et al., 1994; Monaco et al., 1998). Reactivation of both BKV and JCV infection with resulting urinary excretion of viruses readily occurs during conditions of immune suppression or immunocompromization. Conventional PCR has been used to detect and characterize both BKV and JCV DNA in urine of different patient groups, from different human tissues and from urine of pregnant women (Arthur et al., 1989; Markowitz et al., 1991). Regulatory regions of both BKV and JCV have been amplified and characterized from urine of bone marrow and renal transplant patients, HIV positive or negative individuals, patients with various autoimmune diseases. Full-length JCV genomes or DNA sequences have also been isolated and characterized from normal brain tissue, new born infants, immunocompetent older individuals and peripheral blood leucocytes of immunocompetent individuals (Kitamura et al., 1990; Elsner and Dorries, 1992, Dorries et al., 1994; Baksh etal., 2001).

Detection of JCV nucleic acid in urine (Tan et al., 2009; Husseiny et al., 2010), brain autopsy and CNS tissues (Delbue et al., 2008); serum/peripheral blood leukocytes (PBL) (Gu et al., 2003; Tan et al., 2009; Husseiny et al., 2010), bone marrow aspirates (Tan et al., 2009) of normal or non-immunocompromized human subjects, in different age groups, have been reported from many regions of the world. The JCV DNA occurrence in all these studies ranged from 0 to $20 \%$ based on variable sample sizes. Incidences of JCV viruria in different tribal populations showed variations with respect to the groups studied: 56 to $66 \%$ in Native Americans (Agostini et al., 1997), 48 to 67\% in Myanmar tribals (Saruwatari et al., 2002) and 20 to $22 \%$ in African tribals (Chima et al., 1998). We have recorded a relatively high incidence of JCV DNA detection in non-immunosuppressed and healthy human tribal groups in our study (Table I). Out of 77 assayable urine and blood samples $19(\sim 25 \%)$ were scored positive by gel electro- phoresis and PCR product sequencing, and $58(\sim 75 \%)$ samples were scored negative based on the above mentioned criteria.

The non-coding control regions (NCCRs) of JC virus vary considerably among different natural isolates. Archetype like DNA, which lacks sequence repeats in the regulatory region and contains additional sequences, are generally not found in laboratory strains, but has been isolated by molecular cloning from several sources. Rearrangement of NCCRs occurs during passage in cell culture more readily. During reactivation in pregnancy, the shed viruses show archetype-like sequence rearrangement in their NCCRs (Markowitz et al., 1991; Markowitz et al., 1993). Viral strains with divergent NCCRs may have different tissue tropism and also aberrant potential for host cell transformation (Sundsfjord et al., 1994). It has been postulated that the rearrangement in the NCCRs may change the biological properties of polyomaviruses in the due course of a persistent infection, such as the ability to infect different target cells. Reactivation of BKV and/ or JCV infection, with the resultant urinary excretion of virus, may occur in healthy individuals but occurs more frequently under conditions of immunosuppression, especially when T-cell functions are depressed (Chesters et al., 1983; Gardner et al., 1984). JCV infection has been demostrated in B-lymphocytes (Dorries et al., 1994) and JCV specific CD4+ T-lymphocytes have been reported in healthy individuals (Gasnault et al., 2003). Healthy individuals have also been shown to harbour JCV-specific CD8 ${ }^{+}$T-Lymphocytes, principally against $\mathrm{VP} 1_{\mathrm{p} 36}$ epitopes, in their peripheral blood mononuclear cells (Du Pasquier et al., 2004). Fragments of JCV DNA, but not proteins, have been detected in multiple regions of non-immunocompromized and non-PML normal brains (Perez-Liz et al., 2008). The authors have also hypothesized that JCV could spread within normal brain tissue through blood or infected immune cells like B-lymphocytes and remain as integrated or episomal forms within the oligodendrocytes and astrocytes till its initiation of lytic life cycle during immune impairment. Therefore this model raises the possibility of human brain being a secondary site of latency for JCV.

We have investigated the binding sites of known and reported transcription factors/transactivators in the endemic JCV NCCRs and also used computer software to search for additional transcription factors having potential to bind to this region of JCV genome. Two prominent features within the endemic JCV NCCR Box B are the absence, unlike JCV Mad1, of full-length Pura/YB-1 binding pentanucleotide (5'-AGGGAAGGGA-3') (Chen and Khalili, 1995) and the presence of Sp1 binding site (GA Box) (5'-AGGGAGGAGC-3') (Henson etal., 1992) in the same 
Supplementary

Table I

Predicted transcription factor binding sites (TFBS) in the NCCRs of endemic JCV strains NB1, NB2, NB3, NB6 derived using MatInspector Release Professional 8.0.5, March 2011 of Genomatix Software suite v2.5 GmbH. Selected TFBS matches are shown as alphabetically arranged vertebrate matrix families. TFBS search involved both general core promoters $(0.75 /$ Optimized) and vertebrate $(0.75 /$ Optimized $)$ promoter element groups of MatInspector matrix family library version 8.4 (June 2011).

\begin{tabular}{|c|c|c|c|c|c|}
\hline $\begin{array}{c}\text { JCV } \\
\text { strains } \\
\text { (NCCRs) }\end{array}$ & $\begin{array}{l}\text { Matrix } \\
\text { Family }\end{array}$ & Detailed Family Information & Tissue & $\begin{array}{c}\text { Optimized } \\
\text { Similarity } \\
\text { Scores } \\
\end{array}$ & $\begin{array}{l}\text { TF Binding Sequence } \\
\text { (Core Sequence in capital) }\end{array}$ \\
\hline $\mathrm{NB} 1,2,3,6$ & O\$VTBP & $\begin{array}{l}\text { Vertebrate TATA binding } \\
\text { protein factor }\end{array}$ & Ubiquitous & 0.90 & 131-gtataTATAaaaaaaag-147 \\
\hline $\mathrm{NB} 1,2,3,6$ & V\$AP4R & AP4 and related proteins & Ubiquitous & 0.92 & $\begin{array}{l}\text { 214-gctggcAGCTggttggc-230 (-) } \\
\text { and 486-tggccAGCTggtgaca-500 (-) }\end{array}$ \\
\hline $\mathrm{NB} 1,2,3,6$ & V\$BRNF & Brn POU domain factors & $\begin{array}{l}\text { Brain, CNS, Endocrines } \\
\text { System, Neuroglia, Neuron }\end{array}$ & 0.89 & 14-tttgctgTAATtttttgct-32 (-) \\
\hline $\mathrm{NB} 1,2,3,6$ & V\$CAAT & CCAAT binding factors & Ubiquitous & 0.81 & $\begin{array}{l}\text { 185-ccagCCAAgcatgag-199 and } \\
\text { 211-ggagCCAAccagctg-225 }\end{array}$ \\
\hline $\mathrm{NB} 1,2,3,6$ & $\mathrm{~V} \$ \mathrm{E} 2 \mathrm{FF}$ & $\begin{array}{l}\text { E2F-myc activator/cell } \\
\text { cycle regulator }\end{array}$ & Ubiquitous & $0.84-0.85$ & $\begin{array}{l}\text { 458-ctctgGCTCgcaaaaca-474 (-) } \\
\text { and 456-ctggctcgcAAAAcatg-472 (-) }\end{array}$ \\
\hline NB1, 2, 3, 6 & V\$EGRF & $\begin{array}{l}\text { EGR/nerve growth factor } \\
\text { induced protein C \& related } \\
\text { factors }\end{array}$ & $\begin{array}{l}\text { Brain, CNS, Endocrine } \\
\text { System Kidney, Nervous } \\
\text { System, Urinoogenital System }\end{array}$ & 0.88 & $\begin{array}{l}\text { 105-ggaggcggAGGCggcct-121 and } \\
\text { 387-gactatGGGAggggttt-403 (-) }\end{array}$ \\
\hline $\mathrm{NB} 1,2,3,6$ & V\$ETSF & $\begin{array}{l}\text { Human and murine ETS1 } \\
\text { factors }\end{array}$ & $\begin{array}{l}\text { Hematopoietic and Immune } \\
\text { System, Leukocytes, } \\
\text { Lymphocytes, Monocytes }\end{array}$ & $0.88-0.96$ & $\begin{array}{l}\text { 424gcacaaggGGAAgtggaaagc- } 444 \\
\text { 29-caaaaaagGGAAaaacaaggg- } 49 \\
\text { 140-aaaaaaagGGAAggtagggag-160 }\end{array}$ \\
\hline NB1, 2, 3, 6 & V\$FKHD & Fork head domain factors & $\begin{array}{l}\text { APCs, Blood Cells, Immune } \\
\text { System, Leukocytes, } \\
\text { Lymphocytes }\end{array}$ & 0.89 & $\begin{array}{l}\text { 132-tatataTAAAaaaaagg- } 148 \text { and } \\
410 \text {-cacaagTAAAcaaagca-426 }\end{array}$ \\
\hline NB2 & V\$GATA & GATA binding factors & $\begin{array}{l}\text { Blood and Bone Marrow } \\
\text { Cells Hematopoietic System, } \\
\text { Immune System, Leukocytes, } \\
\text { Lymphocytes }\end{array}$ & 0.90 & 199-cctaGATAtgagc-211 \\
\hline $\mathrm{NB} 1,2,3,6$ & V\$HICF & $\begin{array}{l}\text { Krueppel-like } \mathrm{C} 2 \mathrm{H} 2 \text { zinc } \\
\text { finger factors } \\
\text { hypermethylated in cancer }\end{array}$ & $\begin{array}{l}\text { Erythropoiesis, control } \\
\text { of cell proliferation, monocyte } \\
\text { activation }\end{array}$ & 0.88 & $\begin{array}{l}\text { 180-ggcTGCCagccaa-192 and } \\
\text { 221-agcTGCCagccag-349 }\end{array}$ \\
\hline $\mathrm{NB} 1,2,3,6$ & V\$HOMF & $\begin{array}{l}\text { Homeodomain transcription } \\
\text { factors }\end{array}$ & $\begin{array}{l}\text { Blood and Bone Marrow } \\
\text { Cells, Endocrine System, } \\
\text { Hemato poietic System, } \\
\text { Immune System, Leukocytes, } \\
\text { Lymphocytes }\end{array}$ & $0.88-0.95$ & $\begin{array}{l}\text { 13-cagcaaaaAATTactgcaa-31 and } \\
\text { 14-tttgcagtAATTtttgct-32 (-) }\end{array}$ \\
\hline $\mathrm{NB} 1,2,3$ & V\$IKRS & Ikaros zinc finger family & $\begin{array}{l}\text { Antibody-Producing Cells, } \\
\text { Blood Cells, Hematopoietic } \\
\text { System, Immune System, } \\
\text { Leukocytes, Lymphocytes }\end{array}$ & 0.84 & 43-acaagGGAAtttc- 55 \\
\hline NB1, 2, 3, 6 & V\$IRFF & Interferon regulatory factors & $\begin{array}{l}\text { Antibody-Producing Cells, } \\
\text { APCs, Blood, Bone Marrow } \\
\text { Cells, Hematopoietic and } \\
\text { Immune System, Leukocytes, } \\
\text { Lymphocytes, Monocytes } \\
\text { Myeloid Cells, Phagocytes }\end{array}$ & $0.85-0.87$ & $\begin{array}{l}\text { 376-cagttatagtGAAAcccctcc-396; } \\
\text { 429-agggGAAGtggaaagcagcca-449; } \\
\text { and 28-gcaaaaaaggGAAAaacaagg- } 48\end{array}$ \\
\hline $\mathrm{NB} 1,2,3,6$ & V\$MAZF & Myc associated zinc fingers & $\begin{array}{l}\text { Blood Cells, Immune } \\
\text { System, Leukocytes }\end{array}$ & 0.90 & 387-atggGAGGggttt-399 (-) \\
\hline NB1, 2, 3, 6 & V\$MYBL & $\begin{array}{l}\text { Cellular and viral myb-like } \\
\text { transcriptional regulators }\end{array}$ & $\begin{array}{l}\text { Blood and Bone Marrow } \\
\text { Cells, Hematopoietic and } \\
\text { Immune System, Leukocytes } \\
\text { Lymphocytes }\end{array}$ & 0.96 & 370-ctaTAACtgccagtg-384 (-) \\
\hline $\mathrm{NB} 1,2,3,6$ & V\$MZF1 & Myeloid zinc finger 1 factors & $\begin{array}{l}\text { Blood and Bone Marrow } \\
\text { Cells, Hematopoietic and } \\
\text { Immune System, Leukocytes } \\
\text { Myeloid Cells }\end{array}$ & 0.99 & 428-aaGGGGaagtg-438 \\
\hline
\end{tabular}


Table I continued

\begin{tabular}{|c|c|c|c|c|c|}
\hline $\begin{array}{c}\text { JCV } \\
\text { strains } \\
\text { (NCCRs) }\end{array}$ & $\begin{array}{l}\text { Matrix } \\
\text { Family }\end{array}$ & Detailed Family Information & Tissue & $\begin{array}{c}\text { Optimized } \\
\text { Similarity } \\
\text { Scores }\end{array}$ & $\begin{array}{l}\text { TF Binding Sequence } \\
\text { (Core Sequence in capital) }\end{array}$ \\
\hline $\mathrm{NB} 1,2,3,6$ & V\$NEUR & NeuroD, Beta2, HLH domain & $\begin{array}{l}\text { Antibody-Producing Cells, } \\
\text { Blood and Bone Marrow } \\
\text { Cells, Brain, CNS, } \\
\text { Hematopoietic System, } \\
\text { Immune System, Leukocytes, } \\
\text { Lymphocytes, Nervous } \\
\text { System, Neuroglia, Neurons }\end{array}$ & 0.95 & $\begin{array}{l}\text { 216-caaccaGCTGcca-228; } \\
\text { 488-tcacCAGCtggcc-500 and } \\
\text { 489-ggcCAGCtggtg-500 (-) }\end{array}$ \\
\hline $\mathrm{NB} 1,2,3,6$ & V\$NF1F & Nuclear factor 1 & $\begin{array}{l}\text { Brain, Central Nervous } \\
\text { System, Digestive System, } \\
\text { Liver, Nervous System }\end{array}$ & $0.81-0.92$ & $\begin{array}{l}\text { 161-gagctggctggctGCCAgcca-191 (+); } \\
\text { 212-gagccaaccagctGCCAgcca-348; } \\
\text { 433-ctcCTGGctgcttccacttc-453 (-); } \\
\text { 477-gttTTGGcttgtcaccagctg-497; } \\
\text { 161-tggcTGGCagccagccagctc-191 (-); } \\
\text { 165-tggcTGGCtgccagccaagca-195 (+); } \\
\text { 433-gaagTGGAaagcagccaggag-453; } \\
\text { 171-aaactggatggctGCCAgcca-191 (NB6); } \\
\text { 171-tggCTGGcagccatccagttt-191 (-) (NB6); } \\
\text { 175-tggTTGGctggcagccatcca-195 (-) (NB6); } \\
\text { 175-tggaTGGCtgccagccaacca-195 (NB6); } \\
\text { 355-gcccTGGCtgcatgccactgg-375; } \\
\text { 355-ccagTGGCatgcagccagggc-375 (-); } \\
\text { 477-cagcTGGTgacaagccaaaac-497 (-) }\end{array}$ \\
\hline NB1, 2, 3, 6 & V\$NFKB & Nuclear factor kappa B/c-rel & $\begin{array}{l}\text { Blood and Bone Marrow Cells, } \\
\text { Hematopoietic and Immune } \\
\text { System, Leukocytes, Myeloid } \\
\text { Cells, Phagocytes }\end{array}$ & 0.87 & $\begin{array}{l}\text { 45-aagggaatTTCCctg-59 and } \\
\text { 45-cagggaaaTTCCctt-59 (-) }\end{array}$ \\
\hline NB6 & V\$NOLF & $\begin{array}{l}\text { Neuron-specific olfactory } \\
\text { factor }\end{array}$ & $\begin{array}{l}\text { Antibody-Producing Cells, } \\
\text { Blood, Bone Marrow Cells, } \\
\text { Hematopoietic, Immune, } \\
\text { Nervous System, Leukocytes, } \\
\text { Lymphocytes, Neurons }\end{array}$ & 0.88 & 460 -acatgtTCCCctggctgctttcc- $438(-)$ \\
\hline NB2, 3, 6 & V\$P53F & p53 tumor suppressor & Ubiquitous & 0.92 & $\begin{array}{l}\text { 441-aagcagccaggggaaCATGtttt-463 (NB6) } \\
\text { and } \\
452 \text {-ctctggctcgcaaaaCATGttcc-474 (-) (NB6) }\end{array}$ \\
\hline NB6 & V\$PAX3 & PAX-3 binding sites & $\begin{array}{l}\text { Embryonic Structures Muscle, } \\
\text { Skeletal Muscles }\end{array}$ & 0.93 & 187-gagctCATGgttggctggc-202 (-) \\
\hline NB6 & V\$PAX5 & PAX-2/5/8 binding sites & $\begin{array}{l}\text { Antibody-Producing Cells, } \\
\text { Blood Cells, Endocrine System, } \\
\text { Hematopoietic System, } \\
\text { Immune System, Kidney, } \\
\text { Leukocytes, Lymphocytes }\end{array}$ & 0.79 & 177-tatgagCTCAtggttggctggcagccatc-205 (-) \\
\hline NB2, 6 & V\$PAXH & $\begin{array}{l}\text { PAX homeodomain binding } \\
\text { sites }\end{array}$ & $\begin{array}{l}\text { Brain, CNS, Endocrine System, } \\
\text { Nervous System Neurons }\end{array}$ & 0.99 & 16-caaaaaATTAcagca-30 \\
\hline $\mathrm{NB} 1,2,3,6$ & V\$PLAG & Pleomorphic adenoma gene & Brain, CNS, Nervous System & 0.87 & $\begin{array}{l}\text { 223-ccaggGCTCcctctggctggcag-361 and } \\
\text { 348-agaggGAGCcctggctgcatgcc-370 }\end{array}$ \\
\hline $\mathrm{NB} 1,2,3,6$ & V\$PURA & $\begin{array}{l}\text { Pur-alpha binds both single- } \\
\text { stranded and douple-stranded } \\
\text { DNA in a sequence-specific } \\
\text { manner }\end{array}$ & $\begin{array}{l}\text { Brain, CNS, Nervous System, } \\
\text { Neuroglia, Neurons }\end{array}$ & 0.97 & 105-ggAGGCggaggcg-117 \\
\hline $\mathrm{NB} 1,2,3,6$ & V\$RUSH & $\begin{array}{l}\text { SWI/SNF related nucleo- } \\
\text { phosphoproteins with a RING } \\
\text { finger DNA binding motif }\end{array}$ & Ubiquitous & 0.98 & 410-gtttACTTgtg-420 (-) \\
\hline $\mathrm{NB} 1,2,3,6$ & V\$SALL & Spalt-like transcription factors & $\begin{array}{l}\text { Embryonic Structures, Kidney, } \\
\text { Urogenital System }\end{array}$ & 0.96 & 135-atATAAaaaaaag-147 \\
\hline $\mathrm{NB} 1,2,3,6$ & V\$SP1F & GC-Box factors SP1/GC & Ubiquitous & 0.88 & $\begin{array}{l}\text { 151-aggtagGGAGgagctgg-167 } \\
\text { 386-actatgGGAGgggtttc-402 (-) }\end{array}$ \\
\hline NB6 & V\$TALE & $\begin{array}{l}\text { TALE homeodomain class } \\
\text { recognizing TG motifs }\end{array}$ & $\begin{array}{l}\text { Bone Marrow Cells, CNS, } \\
\text { Embryonic Structures, Hema- } \\
\text { topoietic System, Myeloid Cells, } \\
\text { Nervous System, Neurons }\end{array}$ & 0.95 & $\begin{array}{l}\text { 219-ctctggcTGTCagctgg-351 (-) } \\
\text { 217-aaccagctGACAgccag-349 }\end{array}$ \\
\hline
\end{tabular}


Table I continued

\begin{tabular}{|l|l|l|l|l|l|}
\hline $\begin{array}{c}\text { JCV } \\
\text { strains } \\
\text { (NCCRs) }\end{array}$ & $\begin{array}{c}\text { Matrix } \\
\text { Family }\end{array}$ & Detailed Family Information & \multicolumn{1}{|c|}{ Tissue } & $\begin{array}{c}\text { Optimized } \\
\text { Similarity } \\
\text { Scores }\end{array}$ & \multicolumn{1}{c|}{$\begin{array}{c}\text { TF Binding Sequence } \\
\text { (Core Sequence in capital) }\end{array}$} \\
\hline NB6 & V\$XBBF & X-box binding factors & $\begin{array}{l}\text { Antibody-Producing Cells, } \\
\text { blood Cells, Immune System, } \\
\text { Leukocytes, Lymphocytes }\end{array}$ & 0.90 & 441-aagcagccaggGGAAcatg-459 \\
\hline NB6 & V\$YY1F & $\begin{array}{l}\text { Activator/repressor binding } \\
\text { to transcription initiation site }\end{array}$ & Embryonic Structures & 0.82 & 166-ggcagCCATccagtttagcc-186 (-) \\
\hline NB1,2,3,6 & V\$ZF02 & $\begin{array}{l}\text { C2H2 zinc finger transcription } \\
\text { factors 2 }\end{array}$ & $\begin{array}{l}\text { Blood Cells, Immune System } \\
\text { Leukocytes, Lymphocytes }\end{array}$ & 0.87 & 107-ggaggccgaggCCGCctccgcct-129 (-) \\
\hline
\end{tabular}

JCV NB1, NB2, NB3, NB6 showed 99, 140, 144, and 155 total matches respectively. JCV NB3, 5 and 6 being identical, only NB3 was included in the search. Matrix similarity column refers to an optimized similarity match above 0.80 score while a perfect match to the matrix is marked by a maximum score of 1.00. All matches below 0.80 score were excluded in the table. A range of scores for discrete sequences are shown where appropriate. Start and end positions of TF binding sites are numbered according to the aligned NCCR sequences as shown in Figure 1. Matching sequences found in negative strands are indicated as (-); however sequences are numbered along the plus strands. Matching sequences found only in NB6 are indicated within parentheses at the end of the sequences.

region. These features are also exhibited by the archetypal CY, Tibetan LH3, Taiwanese Tai3 and the CentralNorth Indian IN-8 strains (Fig. 2). In the light of these findings (Chen and Khalili, 1995) the significance of partial Pura/YB-1 binding sites within the NCCRs of the endemic circulating JCV vis-a-vis the level of viral $\mathrm{T}$ antigen expression within the tissues needs to be validated through cell culture-based gene expression studies. The terminal two nucleotide deletions in the Pura/YB-1 binding pentanucleotide and the concomitant presence of Sp1 binding GA-Box needs to be investigated with respect to glial cell specific gene expression studies. Cellular tumour suppressor protein p53 is reported to bind to JCV large T antigen to repress viral replication (Staib et al., 1996) and/or directly to and regulate JCV promoter (Ariza et al., 1994). We have found a di-nucleotide deletion within this p53 binding site of endemic JCV strains from Oraon/Munda group but not from the Rabha group (NB6) (Fig. 2). Implications of this deletion in the NCCRs of JCV NB1 to NB5 need to be evaluated in in vivo studies. The predicted TFBS depicted putative binding sites for transcription factors corresponding to thirty-three matrix families (Supplementary Table I). We retained the putative TFBS matches which are reported to be active in cells/tissues such as antibody-producing cells, antigen-presenting cells, bone marrow cells, hematopoietic and immune system, leukocytes, lymphocytes, monocytes, myeloid cells, phagocytes, brain, CNS, endocrine system, kidney, nervous system, urinogenital system. Although the TFBS were common to NB1 to NB6, on a closer look we can see few transcription factors (Neuron-specific Olfactory factor or NOLF, p53 tumor suppressor, TALE homeodomain class recognizing TG motifs or TALE, $\mathrm{X}$-box binding factor or XBBF and Activator/repressor binding to transcription initiation site or YY1F) matching exclusively to either positive $(+)$ or negative $(-)$ strands of NB6 NCCR owing to its sequence differ- ences with that of other endemic NCCRs. While the implications of these finding cannot be guessed at this juncture, the list is likely to provide a hint for a detailed in vivo binding studies to validate hypotheses regarding tissue-specific promoter activities in JCV.

In summary, we have reported for the first time the NCCR architecture of the endemic JCV strains in tribal population groups from north-eastern region of India and have compared their sequences with that of other key JCV strains from Asia. The NCCR sequence analyses were done with regard to transcription factor binding to DNA sequence elements of endemic JCV NCCRs.

\section{Acknowledgements}

The study was supported by a research grant from the Council of Scientific and Industrial Research (CSIR), New Delhi, India awarded to the corresponding author [Sanction number 37 (1446)/10/EMR-II]. Authors also acknowledge the ready help from DBT Bioinformatics facility of North Bengal University, West Bengal in in silico studies.

\section{Literature}

Agostini H.T., C.F. Ryschkewitsch, R. Mory, E.J. Singer and G.L. Stoner. 1997. JC virus (JCV) genotypes in brain tissue from patients with progressive multifocal leukoencephalopathy (PML) and in urine from controls without PML: increased frequency of JCV type 2 in PML. J. Infect. Dis. 176: 1-8.

Agostini H.T., R. Yanagihara, V. Davis, C.F. Ryschkewitsch and G.L. Stoner. 1997. Asian genotypes of JC virus in Native Americans and in a Pacific Island population: markers of viral evolution and human migration. Proc. Natl. Acad. Sci. USA 94: 14542-14546.

Amemiya K., R. Traub, L. Durham and E.O. Major. 1989. Interaction of a nuclear factor-1-like protein with the regulatory region of the human polyomavirus JC virus. J. Biol. Chem. 264: 7025-7032.

Ariza A., J.L. Mate, A. Fernandez-Vasalo, C. Gomez-Plaza, J. Perez-Piteira, M. Pujol and J.J. Navas-Palacios. 1994. p53 and proliferating cell nuclear antigen expression in JC virus-infected cells of progressive multifocal leukoencephalopathy. Hum. Pathol. 25: $1341-1345$. 
Arthur R.R., S. Dagostin and K.V. Shah. 1989. Detection of BK virus and JC virus in urine and brain tissue by the polymerase chain reaction. J. Clin. Microbiol. 27: 1174-1179.

Baksh F.K., S.D. Finkelstein, P.A. Swalsky, G.L. Stoner, C.F. Ryschkewitsch and P.S. Randhawa. 2001. Molecular genotyping of BK and JC viruses in human polyomavirus-associated interstitial nephritis after renal transplantation. Am. J. Kidney. Dis. 38: 354-365.

Boldorini R., E. Omodeo-Zorini, M. Nebuloni, E. Benigni, L. Vago, A. Ferri and G. Monga. 2003. Lytic JC Virus Infection in the Kidneys of AIDS Subjects. Mod. Pathol. 16: 35-42.

Cartharius K., K. Frech, K. Grote, B. Klocke, M. Haltmeier, A. Klingenhoff, M. Frisch, M. Bayerlein and T. Werner. 2005. MatInspector and beyond: promoter analysis based on transcription factor binding sites. Bioinform. 21: 2933-2942.

Chen N.N. and K. Khalili. 1995. Transcriptional regulation of human JC polyomavirus promoters by cellular proteins YB-1 and Pur alpha in glial cells. J. Virol. 69: 5843-5848.

Chesters P.M., J. Heritage and D.J. McCance. 1983. Persistence of DNA sequences of BK virus and JC virus in normal human tissues and in diseased tissues. J. Infect. Dis. 147: 676-684.

Chima S.C., C.F. Ryschkewitsch and G.L. Stoner. 1998. Molecular epidemiology of human polyomavirus JC in the Biaka Pygmies and Bantu of Central Africa. Mem. Inst. Oswaldo. Cruz. 93: 615-23.

Chowdhury M., M. Kundu and K. Khalili. 1993. GA/GC-rich sequence confers Tat responsiveness to human neurotropic virus promoter, JCVL, in cells derived from central nervous system. Oncogene. 8: 887-892.

Cui X., J.C. Wang, A. Deckhut, B.C. Joseph, P. Eberwein, C.L. Cubitt, C.F. Ryschkewitsch, H.T. Agostini and G.L. Stoner. 2004. Chinese strains (Type 7) of JC virus are afro-asiatic in origin but are phylogenetically distinct from the Mongolian and Indian strains (Type 2D) and the Korean and Japanese strains (Type 2A). J. Mol. Evol. 58: 568-583.

Delbue S., E. Branchetti, R. Boldorini, L. Vago, P. Zerbi, C. Veggiani, S. Tremolada and P. Ferrante. 2008. Presence and expression of JCV early gene large T Antigen in the brains of immunocompromised and immunocompetent individuals. J. Med. Virol. 80: 2147-2152.

Devireddy L.R., K.U. Kumar, M.M. Pater and A. Pater. 2000. BAG1 , a novel Bcl-2-interacting protein, activates expression of human JC virus. J. Gen. Virol. 81: 351-357.

Dorries K., E. Vogel, S. Gunther and S. Czub. 1994. Infection of human polyomaviruses JC and BK in peripheral blood leukocytes from immunocompetent individuals. Virol. 198: 59-70.

Du Pasquier R.A., J.E. Schmitz, J. Jean-Jacques, Y. Zheng, J. Gordon, K. Khalili, N.L. Letvin and I.J. Koralnik. 2004. Detection of JC virus-specific cytotoxic T lymphocytes in healthy individuals. J. Virol. 78: 10206-10210.

Elsner C. and K. Dorries. 1992. Evidence of human polyomavirus BK and JC infection in normal brain tissue. Virol. 191: 72-80.

Frisque R.J., G.L. Bream and M.T. Cannella. 1984. Human polyomavirus JC virus genome. J. Virol. 51: 458-469.

Gardner S.D., E.F. Mackenzie, C. Smith and A.A. Porter. 1984. Prospective study of the human polyomaviruses BK and JC and cytomegalovirus in renal transplant recipients. J. Clin. Pathol. 37: 578-586.

Gasnault J., M. Kahraman, M.G. de Goer de Herve, D. Durali, J.F. Delfraissy and Y. Taoufik. 2003. Critical role of JC virusspecific CD4 T-cell responses in preventing progressive multifocal leukoencephalopathy. AIDS 17: 1443-1449.

Gu Z.Y., Q. Li, Y.L. Si, X. Li, H.J. Hao and H.J. Song. 2003. Prevalence of $\mathrm{BK}$ virus and JC virus in peripheral blood leukocytes and normal arterial walls in healthy individuals in China. J. Med. Virol. 70: 600-605.
Hall T.A. 1999. BioEdit: a user-friendly biological sequence alignment editor and analysis program for Windows 95/98/NT. Nucl. Acids. Symp. Ser. 41: 95-98.

Henson J., J. Saffer and H. Furneaux. 1992. The transcription factor Sp1 binds to the JC virus promoter and is selectively expressed in glial cells in human brain. Ann. Neurol. 32: 72-77.

Hou J. and E.O. Major. 2000. Progressive multifocal leukoencephalopathy: JC virus induced demyelination in the immune compromised host. J. Neurovirol. 6(Suppl. 2): S98-S100.

Husseiny M.I., B. Anastasi, J. Singer and S.F. Lacey. 2010. A comparative study of Merkel cell, BK and JC polyomavirus infections in renal transplant recipients and healthy subjects. J. Clin. Virol. 49: $137-140$

Khalili K., J. Gordon and M.K. White. 2006. The polyomavirus, JCV and its involvement in human disease. Adv. Exp. Med. Biol. 577: 274- 287.

Kitamura T., Y. Aso, N. Kuniyoshi, K. Hara and Y. Yogo. 1990. High incidence of urinary JC virus excretion in nonimmunosuppressed older patients. J. Infect. Dis. 161: 1128-1133.

Langer-Gould A., S.W. Atlas, A.J. Green, A.W. Bollen and D. Pelletier. 2009. Progressive multifocal leucoencephalopathy in a patient treated with natalizumab. N. Engl. J. Med. 361:1075-1080.

Lonze B.E. and D.D. Guinty. 2002. Function and regulation of CREB family transcription factors in the nervous system. Neuron. 35: 605-623

Markowitz R.B., B.A. Eaton, M.F. Kubic, D. Latorra, J.A. McGregor and W.S. Dynan. 1991. BK virus and JC virus shed during pregnancy have predominantly archetypal regulatory regions. J. Virol. 65: 4515-4519.

Markowitz R.B., H.C. Thompson, J.F. Mueller, J.A. Cohen and W.S. Dynan. 1993. Incidence of BK virus and JC virus viruria in human immunodeficiency virus-infected and - uninfected subjects. J. Infect. Dis. 167: 13-20.

Marshall L.J., L. Dunham and E.O. Major. 2010. Transcription factor Spi-B binds unique sequences present in the tandem repeat promoter/enhancer of JC virus and supports viral activity. J. Gen. Virol. 9: 3042-3052.

Monaco M.C., P.N. Jensen, J. Hou, L.C. Durham and E.O. Major. 1998. Detection of JC virus DNA in human tonsil tissue: evidence for site of initial viral infection. J. Virol. 72: 9918-9923.

Padgett B.L., D.L. Walker, G.M. Zu Rhein, R.J. Echroade and B.H. Dessel. 1971. Cultivation of papova-like virus from human brain with progressive multifocal leucoencephalopathy. Lancet. 1: 1257-1260.

Perez-Liz, G., L. Del Valle, A. Gentilella, S. Croul and K. Khalili. 2008. Detection of JC virus DNA fragments but not proteins in normal brain tissue. Ann. Neurol. 64: 379-387.

Raj G.V. and K. Khalili. 1994. Identification and characterization of a novel GGA/C-binding protein, GBP-i, that is rapidly inducible by cytokines. Mol. Cell. Biol. 14: 7770-7781.

Ranganathan P.N. and K. Khalili. 1993. The transcriptional enhancer element, $\varkappa \mathrm{B}$, regulates promoter activity of the human neurotropic virus, JCV, in cells derived from the CNS. Nuc. Acids. Res. 21: 1959-1964.

Romagnoli L., I.K. Sariyer, J. Tung, M. Feliciano, B.E. Sawaya, L. Del Valle, P. Ferrante, K. Khalili, M. Safak and M.K. White. 2008. Early growth response- 1 protein is induced by JC virus infection and binds and regulates the JC virus promoter. Virol. 375: 331-341.

Romagnoli L., H.S. Wollebo, S.L. Deshmane, R. Mukerjee, L. Del Valle, M. Safak, K. Khalili and M.K. White. 2009. Modulation of JC virus transcription by C/EBPbeta. Virus. Res. 146: 97-106. Sadowska B., R. Barrucco, K. Khalili and M. Safak. 2003. Regulation of human polyomavirus JC virus gene transcription by AP-1 in glial cells. J. Virol. 77: 665-672. 
Saruwatari L., H.Y. Zheng, T. Takasaka, C. Sugimoto, E. Sakai, B. Bo, N.N. Aung, T. Kitamura, Y. Yogo and N. Ohno. 2002. Peopling of Myanmar as demonstrated by genotyping of urinary JC virus DNA. Anthropol. Sc. 110: 235-249.

Staib C., J. Pesch, R. Gerwig, J.K. Gerber, U. Brehm, A. Stangl and F. Grummt. 1996. p53 inhibits JC virus DNA replication in vivo and interacts with JC virus large T-antigen. Virol. 219: 237-246.

Sugimoto C., M. Hasegawa, H.Y. Zheng, V. Demenev, Y. Sekino, K. Kojima, T. Honjo, H. Kida, T. Hovi, T. Vesikari, J.A. Schalken, K. Tomita, Y. Mitsunobu, H. Ikegaya, N. Kobayashi, T. Kitamura and Y. Yogo. 2002. JC virus strains indigenous to northeastern Siberians and Canadian Inuits are unique but evolutionally related to those distributed throughout Europe and Mediterranean areas. J. Mol. Evol. 55: 322-335.

Sundsfjord A., A.R. Spein, E. Lucht, T. Flaegstad, O.M. Seterns and T. Traavik. 1994. Detection of BK virus DNA in nasopharyngeal aspirates from children with respiratory infections but not in saliva from immunodeficient and immunocompetent adult patients. J. Clin. Microbiol. 32: 1390-1394.

Tan C.S., B.J. Dezube, P. Bhargava, P. Autissier, C. Wuthrich, J. Miller and I.J. Koralnik. 2009. Detection of JC virus DNA and proteins in the bone marrow of HIV-positive and HIV-negative patients: implications for viral latency and neurotropic transformation. J. Infect. Dis. 199: 881-888.

Thompson J.D., T.J. Gibson, F. Plewniak, F. Jeanmougin and D.G. Higgins. 1997. The CLUSTAL_X windows interface: flexible strategies for multiple sequence alignment aided by quality analysis tools. Nuc. Acids. Res. 25: 4876-4882.

Wegner M., D.W. Drolet and M.G. Rosenfeld. 1993. Regulation of JC virus by the POU-domain transcription factor Tst-1: implications for progressive multifocal leukoencephalopathy. Proc. Natl. Acad. Sci. USA 90: 4743-4747.

Wollebo H.S., S. Melis, K. Khalili, M. Safak and M.K. White. 2012. Cooperative roles of NF- $\kappa$ B and NFAT4 in Polyomavirus JC regulation at the KB control element. Virol. 432: 146-154. 
